\title{
Pulpal response of dogs primary teeth to an adhesive system or to a calcium hydroxide cement
}

\section{Resposta pulpar de dentes decíduos de cães a um sistema adesivo ou ao cimento de hidróxido de cálcio}

\author{
Rosângela Almeida RIBEIRO* \\ Silvio Issáo MYAKI** \\ Marco Antônio GIOSO*** \\ Ney Soares de ARAÚJO****
}

\begin{abstract}
RIBEIRO, R. A.; MYAKI, S. I.; GIOSO, M. A.; ARAÚJO, N. S. Pulpal response of dogs primary teeth to an adhesive system or to a calcium hydroxide cement. Pesq Odont Bras, v. 14, n. 1, p. 47-52, jan./mar. 2000.

The aim of this study was to evaluate the pulpal response of dogs primary teeth to an adhesive system or to a calcium hidroxide cement after mechanic exposure of the pulp. Three mongrel dogs were used and ten class $\mathrm{V}$ cavities were prepared on their teeth. A mechanic pulp exposure was produced with a sterile exploratory probe in the central portion of each cavity and bleeding was controlled with dry sterile cotton pellets. Enamel, dentin and the site of the pulp exposure of five teeth were etched with $35 \%$ phosphoric acid followed by the application of an adhesive system (Scotchbond Multi-Purpose - 3M). In the other five teeth, calcium hydroxide cement (Hydro C - Dentsply) was applied on the site of the pulp exposition before application of the adhesive system (Scotchbond Multi-Purpose - 3M). All teeth were restored with a resin composite $(Z-100-3 \mathrm{M})$. After 7,30 or 45 days the dogs were anesthetized and perfused with saline followed by a solution of neutral buffered formalin. Maxilla and mandible were sectioned into three parts and placed in a solution for demineralization. Following bone demineralization, all teeth were cut, trimmed, embedded in paraffin and longitudinally cut. Then, the teeth were stained with hematoxilin and eosin and observed under a light microscope. The results obtained with the treatments proposed in this study showed the presence and persistence of an inflammatory response of different intensities at the three experimental periods. There was no variation in the inflammatory response regarding the different treatments performed.
\end{abstract}

UNITERMS: Dental pulp; Adhesive system; Calcium hydroxide; Primary tooth.

\section{INTRODUCTION}

Direct pulp capping of primary teeth has been widely discussed for many years. It is expected that after pulp exposure, the direct application of an appropriate material promotes deposition of a mineralized dentin bridge and maintains pulp vitality ${ }^{15}$.

This procedure is usually performed with calcium hydroxide formulations, which have bactericidal effect, but histological investigations have also reported a necrotic zone near this material. In other cases, a reparative dentin is formed under calcium hydroxide formulations and a bridge of dentin closes the pulp exposure ${ }^{12}$. However, depo- sition of hard tissue does not seem to be an exclusive property of those dental materials with calcium hydroxide in their compositions. Results obtained by COX et al. ${ }^{4}$ have suggested that neither $\mathrm{Ca}(\mathrm{OH})_{2}$ or hydroxil ion nor the $\mathrm{pH}$ of the utilized material are necessary for the initiation of pulp healing or reparation of the affected area with hard tissue. HANKS et al. ${ }^{6}$ have suggested that this phenomenon seems to be a natural response of the pulp when it is exposed to an irritation of low intensity. COX et al. ${ }^{5}$ demonstrated that a statistically significant number of dentin bridges contain multiple tunnel defects, which communicate with the pulp. This kind of dentin bridge fails to provide

\footnotetext{
* Assistant Professor, Department of Pediatric Dentistry, School of Dentistry, Federal University of Juiz de Fora.

** Assistant Professor, Department of Pediatric Dentistry, School of Dentistry, São Paulo State University (UNESP) - São José dos Campos.

*** Assistant Professor, Department of Surgery Technique; **** Professor and Chair, Department of Oral Pathology - School of Dentistry, University of São Paulo.
} 
RIBEIRO, R. A.; MYAKI, S. I.; GIOSO, M. A.; ARAÚJO, N. S. Pulpal response of dogs primary teeth to an adhesive system or to a calcium hydroxide cement. Pesq Odont Bras, v. 14, n. 1, p. 47-52, jan./mar. 2000.

a hermetic sealing for the underlying pulp and microleakage in this region may be the cause of recurrent pulp infections. The authors have emphasized the necessity of employing biologically relevant measures for providing a sealing of long-term at restorations margins. Medicaments composed of calcium hydroxide only are not able to avoid microleakage after direct pulp capping.

In reality, the biocompatibility of dental materials is related with their capacity of avoiding penetration of bacteria at the tooth-restoration interface. This situation is achieved when the new adhesive systems are used and the hybrid layer is formed between dentin and restorative material. For this reason, it has been suggested that in permanent teeth, the direct pulp capping should be done with an adhesive system ${ }^{1,7,8,9,11,14}$.

Nevertheless, there are few reports concerning the indication of this technique for primary teeth. Thus, after a mechanic pulp exposure, this study evaluated the histological response of the pulp tissue of primary teeth of dogs to an adhesive system or to calcium hydroxide cement.

\section{MATERIALS AND METHODS}

The sample of this study was composed of thirty maxillary or mandibular primary teeth of three mongrel dogs that weighed $2.0 \mathrm{~kg}$ and were from 45 to 60 -days-old. The animals were divided into Groups I, II and III, according to the experimental periods of 7,30 and 45 days, respectively. In each group, teeth were selected to be treated either with the total etching technique or with calcium hydroxide firstly applied as a liner.

All treatments were carried out under general anesthesia at the School of Veterinary Medicine and Zootechny, University of São Paulo, Brazil. The teeth were cleaned with a solution of $2 \%$ chlorexidine, and ten class $\mathrm{V}$ cavities were prepared on their facial surfaces. Then, a sterile exploratory probe was used for creating a pulp exposure on the central portion of each cavity. The pulp exposure had a diameter of about $0.5 \mathrm{~mm}$, and bleeding was controlled by dry sterile cotton pellets.

In each animal, ten prepared cavities were divided in two groups according to the proposed treatment. Enamel, dentin, and pulpal tissue of five cavities were etched with 35\% phosphoric acid for 15 seconds, rinsed thoroughly and air dried for 2 seconds to remove water excess, though leaving a moist dentin. Primer and adhesive (Scotchbond Multi-Purpose - 3M) were applied and light cured for 20 seconds.

The other five teeth received a layer of calcium hydroxide cement (Hydro C - Dentsply) on the pulp exposition before the application of the adhesive system. All teeth were restored with resin composite $(Z-100-3 \mathrm{M})$ and light cured for 40 seconds with a curing unit (Optilux 150 - Demetron) with light intensity of $500 \mathrm{~mW} / \mathrm{cm}^{2}$. Restorations were polished with low-speed polishing cups and points (Enhance - Dentsply). Then, all restorations were etched and an unfilled resin (Fortify - Bisco) was applied and light cured for 20 seconds.

At the time intervals of 7,30 or 45 days, the animals were anesthetized and perfused with saline followed by a solution of neutral buffered formalin. Maxilla and mandible were sectioned into three parts and placed in 10\% formalin solution and then in another solution for demineralization. Following bone demineralization, all teeth were trimmed, embedded in paraffin an cut longitudinally to obtain semi-serial sections of $7 \mu \mathrm{m}$. The specimens were stained with $\mathrm{H} \& \mathrm{E}$ (hematoxylin and eosin) and examined under a light microscope.

Histopathological analysis evaluated the presence or absence of pulp inflammation, its extension and intensity as well as the presence or absence of reparative dentin. The histopathological evaluation of the specimens was done in a blind test since they were not marked with the performed treatment, and it was carried out by only one author (N. S. A.).

\section{RESULTS}

Seven days after treatment, the specimens from Group I, treated by total etching technique, showed an inflammatory infiltrate that affected most of the pulp tissue with marked presence of mononuclear cells (Figure 1). Some specimens also had polymorphonuclear cells, neutrophils, leukocytes and microabscesses. In those specimens treated with calcium hydroxide, there was a mild chronic inflammatory infiltrate at the exposure site only (Figure 2), and fibroblast proliferation could also be observed. One of the specimens showed an outline of mineralization next to the original site of the exposure, which had a structure similar to a dentin bridge.

After 30 days, the specimens of Group II, that had been treated by the total etching technique, 
RIBEIRO, R. A.; MYAKI, S. I.; GIOSO, M. A.; ARAÚJO, N. S. Pulpal response of dogs primary teeth to an adhesive system or to a calcium hydroxide cement. Pesq Odont Bras, v. 14, n. 1, p. 47-52, jan./mar. 2000.

showed an intensive mononuclear inflammatory infiltrate. Disorganization of the pulp structure and microabscesses could be noticed (Figure 3).

On the other hand, the specimens treated with calcium hydroxide exhibited a more discrete infiltrate of chronic inflammatory cells and preservation of pulp vitality (Figure 4). However, two specimens of this group also presented a more intensive inflammatory response.

FIGURE 1 - Tooth treated with total etching technique, 7-day-period. Intense inflammatory infiltrate under exposure extending to the remaining pulp tissue

(hematoxylin and eosin; original magnification $\mathrm{X} 40$ ).

FIGURE 2 - Tooth treated with $\mathrm{Ca}(\mathrm{OH})_{2}$, 7-day-period. Moderate inflammatory response under pulp exposure (hematoxylin and eosin; original magnification $\mathrm{X} 40$ ).

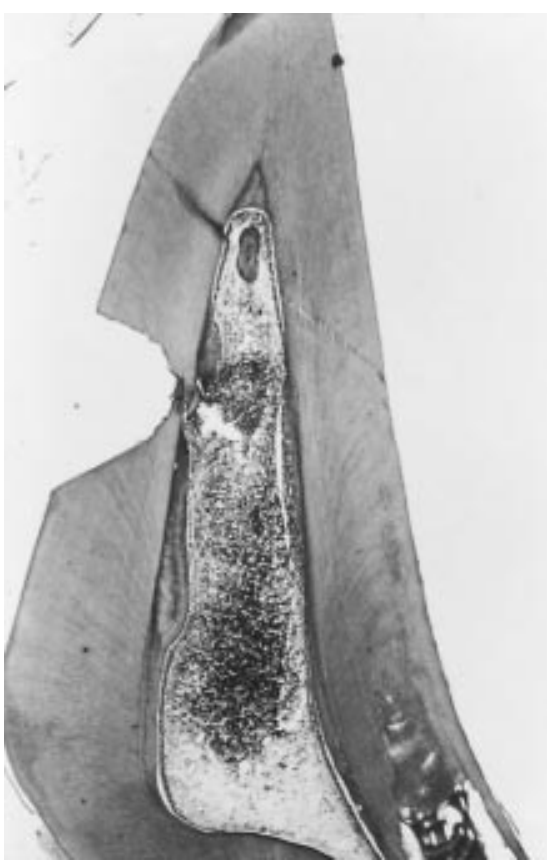

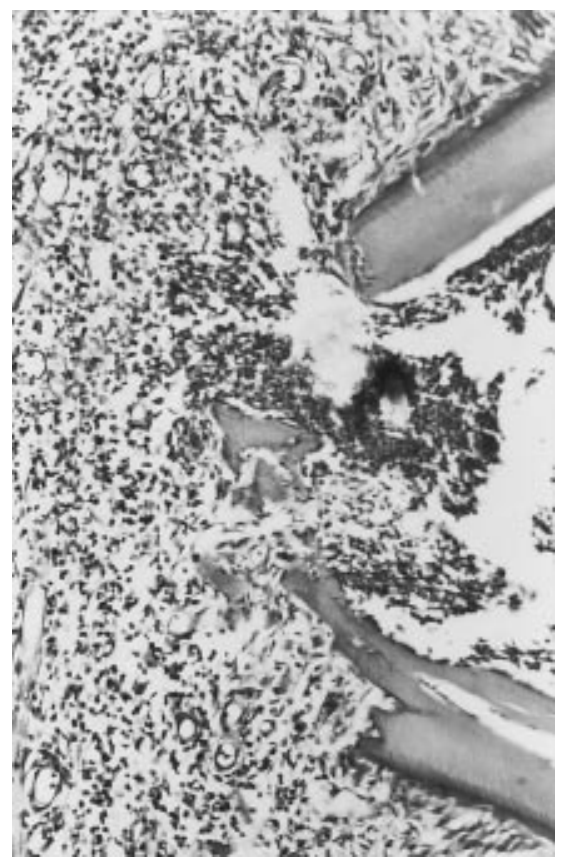

FIGURE 3 - Tooth treated with total etching technique, 30-day-period. Intense mononuclear inflammatory infiltrate within disorganized pulp tissue (hematoxylin and eosin; original magnification $X$ 400).

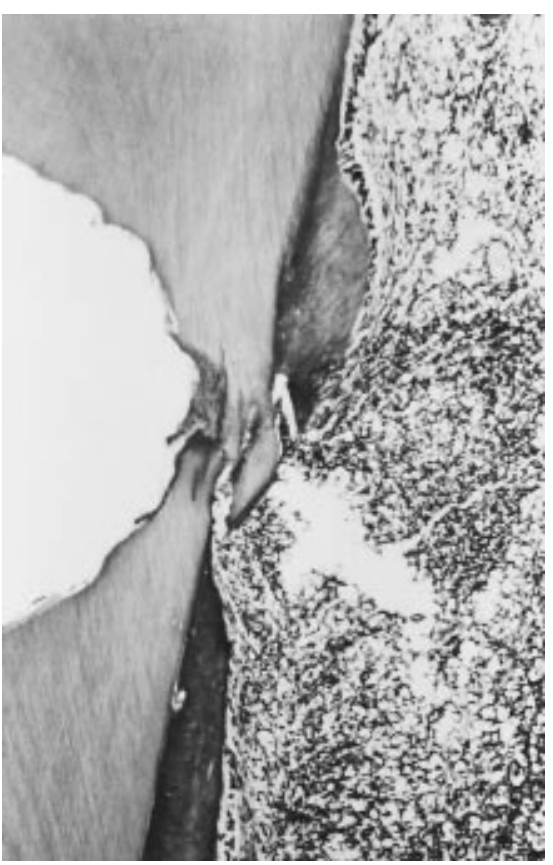

FIGURE 4 - Tooth treated with $\mathrm{Ca}(\mathrm{OH})_{2}$, 30-day-period. Moderate mononuclear inflammatory infiltrate with preservation of pulp tissue including odontoblasts (hematoxylin and eosin; original magnification $X$ 400). 
RIBEIRO, R. A.; MYAKI, S. I.; GIOSO, M. A.; ARAÚJO, N. S. Pulpal response of dogs primary teeth to an adhesive system or to a calcium hydroxide cement. Pesq Odont Bras, v. 14, n. 1, p. 47-52, jan./mar. 2000.

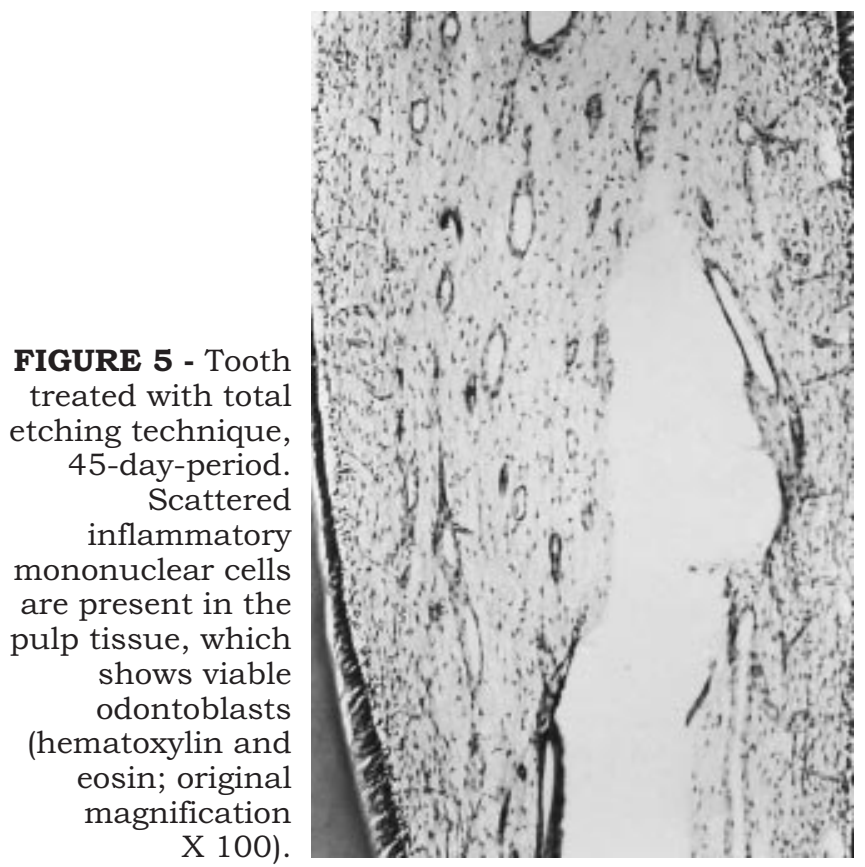

mononuclear cells were evident and, in the other one, neutrophils were present. Other specimens treated with calcium hydroxide exhibited the normal characteristics of pulp tissue (Figure 6).

\section{DISCUSSION}

In the present study the exposed pulp of primary teeth of dogs were histopathologically evaluated. This procedure was accomplished either after the application of $35 \%$ phosphoric acid or calcium hydroxide cement on the pulp exposition.

The inflammatory infiltrate at the seventh day was more intensive and extensive in those teeth treated with the total etching technique. After 30 days, these specimens still exhibited an intensive inflammatory infiltrate. However, two specimens treated with calcium hydroxide did not present an evidently different response when they were compared with those specimens treated with the total etching technique.

There was a clear variation of the pulp infiltrate after 45 days, for both treatments. Pulps of two specimens treated with the total etching technique exhibited normal characteristics and, in the other ones, a mononuclear inflammatory infiltrate was present. Regarding the treatment with calcium hydroxide, pulps of two specimens exhibited normal aspects. However, in the other specimens an inflammatory infiltrate either with mononuclear cells or neutrophils could be observed.

These observations have demonstrated a vari-

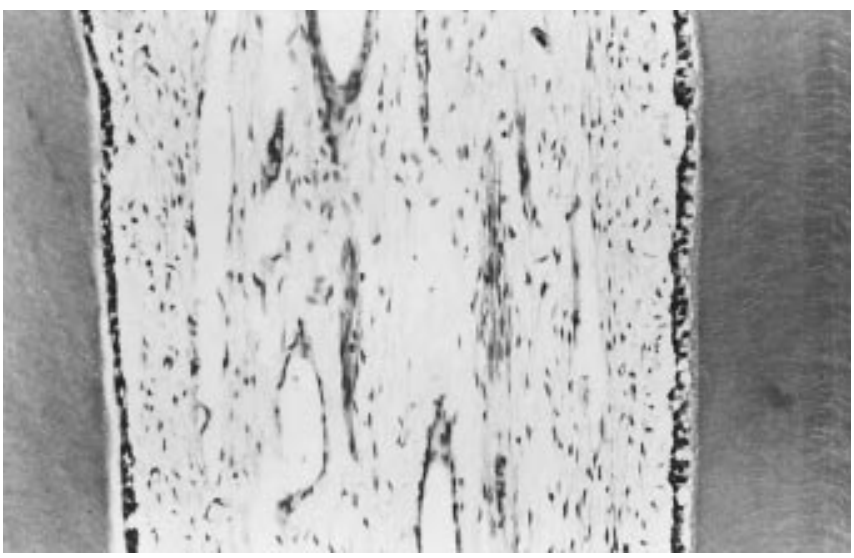

FIGURE 6 - Tooth treated with $\mathrm{Ca}(\mathrm{OH})_{2}$, 45-day-period. Pulp tissue exhibiting normal characteristics (hematoxylin and eosin; original magnification $X 100$ ).

ety of responses from the pulp tissue to both treatments, and that could be associated with deep maceration of the pulp and with the inclusion of dentin chips and medicaments into the pulp during its mechanic exposure. It is relatively common when standardized clinical exposures are made ${ }^{15}$.

When the total etching technique was performed, the histopathological characteristics observed in this study were similar to those reported by ARAÚJO et al. ${ }^{2}$ for human primary teeth. In this study, despite the excellent clinical and radiographic results, the histopathological analysis showed that this technique is not able to promote a calcified dentin bridge at the site of pulp exposition.

COX et $a .^{4}$ have demonstrated that bacterial penetration at the tooth-restoration interface is the main cause of pulp injuries. Thus, a perfect sealing of such interface avoids bacterial penetration and is a basic condition for maintenance of pulp vitality ${ }^{13}$.

The hybrid layer is formed after removal of the smear layer by the adhesive system and it is responsible for linking the deeper undermineralized dentin and the composite restorative material ${ }^{16}$. In this way, formation of the hybrid layer has a clinical significance because it provides an effective sealing at the tooth-restoration interface and prevents bacterial penetration through it.

Recent studies have shown that the hybrid layer can be formed not only in permanent teeth but also in primary ones ${ }^{3,10}$. Nevertheless, the results of this study may be a reflection of an imperfect formation of the hybrid layer, since it was performed on dogs and not on human beings.

The results found for both treatments showed 
RIBEIRO, R. A.; MYAKI, S. I.; GIOSO, M. A.; ARAÚJO, N. S. Pulpal response of dogs primary teeth to an adhesive system or to a calcium hydroxide cement. Pesq Odont Bras, v. 14, n. 1, p. 47-52, jan./mar. 2000.

the presence of a persistent inflammatory infiltrate which had different intensities in the different experimental periods. Under the experimental conditions of this study, there was no difference between the proposed treatments. These findings give support to recommend further studies on this subject, utilizing a greater sample in order to provide more conclusive results.

\section{CONCLUSIONS}

Based on the results of this study, it could be concluded that:

- Group I (results after seven days of observation): the specimens treated with the total etching technique exhibited more extensive and in- tensive pulp inflammatory response than that observed in those teeth treated with calcium hydroxide.

- Group II (results after thirty days of observation): in the specimens treated with the total etching technique, the pulpal inflammatory response, observed at that moment, was still more intensive and extensive than the one present in the specimens treated with calcium hydroxide.

- Group III (results after forty five days of observations): there was a large variation of pulpal reaction for both treatments performed. It varied from normal pulp tissue to a persistent inflammatory infiltrate.

RIBEIRO, R. A.; MYAKI, S. I.; GIOSO, M. A.; ARAÚJO, N. S. Resposta pulpar de dentes decíduos de cães a um sistema adesivo ou ao cimento de hidróxido de cálcio. Pesq Odont Bras, v. 14, n. 1, p. 47-52, jan./mar. 2000.

O objetivo deste estudo foi de avaliar a resposta pulpar de dentes decíduos de cães à um sistema adesivo ou a um cimento de hidróxido de cálcio após exposição mecânica da polpa. Foram utilizados três cães sem raça definida, e nestes foram realizados dez preparos cavitários classe V. Uma exposição pulpar mecânica foi produzida com uma sonda exploradora esterilizada, na porção central de cada cavidade. A hemorragia foi controlada com "bolinhas" de algodão esterilizadas. O esmalte, dentina e local da exposição pulpar de cinco dentes foram condicionados com ácido fosfórico a $35 \%$, seguido da aplicação de um sistema adesivo (Scotchbond Multi-Uso - 3M). Nos outros cinco dentes, um cimento de hidróxido de cálcio (Hydro C - Dentsply) foi aplicada no local da exposição pulpar antes da aplicação do mesmo sistema adesivo. Todos os dentes foram restaurados com uma resina composta (Z-100 - 3M). Após 7, 30 ou 45 dias os cães foram anestesiados e perfundidos com solução salina seguida de uma solução de formalina neutra tamponada. A maxila e a mandíbula foram seccionadas em três partes e estocadas em uma solução para desmineralização. Após a desmineralização óssea, todos os dentes foram cortados, incluídos em parafina e seccionados longitudinalmente. A seguir todos os dentes foram corados com hematoxilina e eosina e observados em microscópio de luz. Os resultados demonstraram a presença e persistência de uma resposta inflamatória de diferentes intensidades nos três periodos experimentais. Não houve variação na resposta inflamatória pelos diferentes tratamentos propostos.

UNITERMOS: Polpa dentária; Sistema adesivo; Hidróxido de cálcio; Dente decíduo.

\section{BIBLIOGRAPHIC REFERENCES}

1. AKIMOTO, N.; MOMOI, Y.; KOHNO, A. et al. Biocompatibility of Clearfil Liner Bond 2 and Clearfil AP-X system on nonexposed and exposed primate teeth. Quintessence Int, v. 29, n. 3, p. 177-187, Mar. 1998.

2. ARAÚJO, F. B.; BARATA, J. S.; PALMINI, A. L. et al. Clinical, radiographical and histopathological analyses of primary teeth submitted to direct pulp capping with an adhesive system. J Dent Res, v. 77, n. 5, p. 1162, May 1998. (Abstract n.153).

3. ARAÚJO, F. B.; GARCÍA-GODOY, F.; ISSÁO, M. A comparison of three resin bonding agents to primary tooth dentin. Pediatr Dent, v. 19, n. 4, p. 253-257, July/Aug. 1997.

4. COX, C. F.; KEALL, C. L.; KEALL, H. J. et al. Biocompatibility of surface-sealed dental materials against exposed pulps. J Prosthet Dent, v. 57, n. 1, p. 1-8, Jan. 1987.

5. COX, C. F.; SÜBAY, R. K.; OSTRO, E. et al. Tunnel defects in dentin bridges: their formation following direct pulp capping. Oper Dent, v. 21, n. 1, p. 4-11, Jan./Feb. 1996.

6. HANKS, C. T.; BERGENHOLTZ, G.; KIM, J. S. Protein synthesis in vitro, in the presence of $\mathrm{Ca}(\mathrm{OH})_{2}$-containing pulp-capping medicaments. J Oral Pathol, v. 12, n. 5, p. 356-365, Oct. 1983.

7. HEITMANN, T.; UNTERBRINK, G. Direct pulp capping with a dentinal adhesive resin system: a pilot study. Quintessence Int , v. 26, n. 11, p. 765-770, Nov. 1995.

8. KANCA III, J. Replacement of a fractured incisor fragment over pulpal exposure: a long-term case report. Quintessence Int, v. 27, n. 12, p. 829-832, Dec. 1996.

9. KITASAKO, Y.; INOKOSHI, S.; FUJITANI, M. et al. Short-term reaction of exposed monkey pulp beneath adhesive resins. Oper Dent, v. 23, n. 6, p. 308-317, Nov./Dec. 1998.

10. NÖR, J. E.; FEIGAL, R. J.; DENNISON, J. B. et al. Dentin bonding: SEM comparison of the dentin surface in pri- 
RIBEIRO, R. A.; MYAKI, S. I.; GIOSO, M. A.; ARAÚJO, N. S. Pulpal response of dogs primary teeth to an adhesive system or to a calcium hydroxide cement. Pesq Odont Bras, v. 14, n. 1, p. 47-52, jan./mar. 2000.

mary and permanent teeth. Pediatr Dent, v. 19, n. 4, p. 246-252, July-Aug. 1997.

11. PEREIRA FILHO, A. A. Q.; LINS FILHO, A. J.; COELHO, A. J. M. et al. Avaliação clínica e histológica da polpa dental de humanos jovens 6 dias após seu condicionamento com ácido fosfórico a 37\%. Rev Bras Odontol, v. 53, n. 1, p. 30-32, jan./fev. 1996.

12. SCHRÖDER, U. A 2-year follow-up primary molars, pulpotomized with a gentle technique and capped with calcium hydroxide. Scand J Dent Res, v. 86, n. 4, p. 273-278, July 1978.

13. SNUGGS, H. Á.; COX, C. F.; POWELL, C. S. et al. Pulpal healing and dentinal bridge formation in an acidic envi- ronment. Quintessence Int, v. 24, n. 7, p. 501-510, July 1993.

14. TSUNEDA, Y.; HAYAKAWA, T.; YAMAMOTO, H. et al. A histopathological study of direct pulp capping with adhesive resins. Oper Dent, v. 20, n. 6, p. 223-229, Nov./Dec. 1995.

15. TURNER, C.; COURTS, F. J.; STANLEY, H. R. A histological comparison of direct pulp capping agents in primary canines. ASDC J Dent Child, v. 54, n. 6, p. 423-428, Nov./Dec. 1987.

16. VAN MEERBEEK, S.; INOKOSHI, S.; BRAEM, M. et al. Micromorphological aspects of the resin-dentin interdiffusion zone with different dentin adhesive systems. J Dent Res, v. 71, n. 8, p. 1530-1540, Aug. 1992.

Recebido para publicação em 19/10/99

Enviado para reformulação em 12/12/99

Aceito para publicação em 24/02/00 